\title{
Transformation of the Security and Intelligence Services in the Czech Republic
}

\section{Luděk Michálek and Ladislav Pokorný}

Police Academy of the Czech Republic in Prague, http://www.polac.cz

\begin{abstract}
This article describes the process of transformation of the security and intelligence apparatus of Czechoslovakia and the Czech Republic from the totalitarian, Soviet bloc country model to the modern democratic system of today. The authors describe the main events, key organizational and legal changes, and the role of the main actors in the transformation process. They analyze the experience and provide recommendations for solving the remaining challenges facing the Czech intelligence community.
\end{abstract}

Keywords: intelligence, secret police, transformation, Czechoslovakia, Czech Republic.

\section{Introduction}

In 1989, Czechoslovakia was an integral part of the Soviet bloc, a member of the Warsaw Pact and, although there were significant changes in the Soviet Union weakening its power over its satellites, the then top Czechoslovak officials still kept their traditional, very rigid positions. This same situation was also to be found in the security apparatus, the organizational structure that mirrored the Soviet structure and still kept very close ties with its Soviet "big brother." The change of power during the so-called Velvet Revolution in November 1989 was relatively peaceful. It was followed by significant changes in the whole of Czech society, including a transformation of the security apparatus from being an organization that suppressed its own citizens with the aim of maintaining the power of the ruling Communist Party to an organization protecting a democratic society and the civil rights of its citizens.

Although there is a great deal of specific information available, there are also many very personal and subjective opinions, views, and sources dealing with this issue. The authors will primarily describe the main events, introducing organiza- 
tional and legal changes, in order to arrive at certain conclusions, some lessons learned, and recommendations. Although every attempt will be made to be as objective as possible, some statements, obviously, will reflect the personal and subjective opinions of the authors predominantly and cannot be considered as an official statement of the Czech intelligence community.

\section{Structure and Tasks of the State Security Apparatus in 1989}

The structure and the mandate of state security in Czechoslovakia in 1989 were very similar to those found in the Soviet Union model as was the case in most of the former Soviet bloc countries:

- The security apparatus was very united and managed by the ruling communist party.

- Intelligence tasks were conducted by the units, the character of which was more of the secret political police (especially those focused on domestic issues) than that of a typical intelligence service as understood in democratic societies.

- The legislative framework of the state security apparatus was very vague. As described below, only the existence of the State Security organization was stipulated by the Act on the National Security Corps. All other regulations and directives were internal and publicly inaccessible. They were adopted at a ministerial or even lower level, and most of them were classified. ${ }^{1}$

Generally, there are four basic tasks of intelligence activities:

- offensive military intelligence,

- offensive foreign intelligence, the so-called "civilian intelligence service,"

- defensive military counter-intelligence,

- defensive internal security service, the so-called "civilian counter-intelligence service." 2

The State Security fulfilled all of these tasks except for offensive military intelligence. The State Security organization was, until 1989, an integral part of the National Security Corps (Sbor národní bezpečnosti - SNB), and its main task was to implement the policies of the Communist Party of Czechoslovakia (KSČ) and

1 Original internal orders and directives for the activity of the State Security are available on Rozkazy a směrnice (Orders and Directives), Ústav pro studium totalitních režimů (Institute for the Study of Totalitarian Regimes), https://www.ustrcr.cz/uvod/rozkazysmernice/.

2 Petr Zeman, Intelligence Services of the Czech Republic: Current Legal Status and Its Development (Geneva: DCAF, January 2007), https://www.dcaf.ch/sites/default/files/ publications/documents/zeman_intelligence-services-czech.pdf. 
to protect the socialist system. ${ }^{3}$ The National Security Corps was a united security organization, which consisted of two main bodies - Public Security (Veřejná bezpečnost - VB) and State Security (Státní bezpečnost - StB). Public Security was responsible for public order and all general criminal activity, while State Security was responsible for the areas of anti-regime activities, counter-intelligence (including military counter-intelligence), and intelligence operations abroad. ${ }^{4}$

In 1989, the Operative and investigative State Security units were organized as directorates of the National Security Corps as follows:

- 1st Directorate of the National Security Corps (I. správa Sboru národní bezpečnosti) - external (offensive) intelligence service;

- 2nd Directorate of the Federal Ministry of Interior - internal (defensive) counter-intelligence service, this unit was in the strict sense of the word generally considered to be "State Security";

- 3rd Directorate of the National Security Corps - Military Counter-intelligence (Vojenská kontrarozvědka - VKR);

- 4th Directorate of the National Security Corps- specialized surveillance unit;

- 5th Directorate of the National Security Corps - protection of the (communist) party and constitutional officials;

- $\quad 6$ th Directorate of the National Security Corps - intelligence technologies and equipment;

- 12 th Directorate of the National Security Corps - internal (defensive) counter-intelligence service for the Slovak Socialistic Republic, ${ }^{5}$

- 13th Directorate of the National Security Corps - specialized SIGINT unit (external and internal);

- Investigation Directorate of State Security (Správa vyšetřování Státní bezpečnosti) - the specialized unit responsible for conducting criminal proceedings in the area of State Security responsibility.

Offensive military intelligence tasks were conducted by the only service existing outside of the State Security structure (similar to the Soviet Union GRU) -

3 The above-mentioned main tasks were assigned to the Corps in the preamble of Act No. 40/174 Coll. on the National Security Corps. It reflected the then valid Czechoslovak constitution from 1960 which codified the leading role of the Czechoslovak Communist Party in the society. See Zákon 100/1960 Sb., Ústava Československé socialistické republiky (Act No. 100/1960 Coll., Constitution of the Czechoslovak Socialistic Republic), www.psp.cz/docs/texts/constitution_1960.html.

4 For more information see Kieran Williams and Dennis Deletant, Security Intelligence Services in New Democracies. The Czech Republic, Slovakia and Romania (Basingstoke, UK: Palgrave Macmillan, 2001), 25-54.

5 The Czechoslovak Socialistic Republic as a federal state consisted, since 1968, of the Czech Socialistic Republic and the Slovak Socialistic Republic. 
The Intelligence Directorate of the General Staff (Zpravodajská správa generáIního štábu - ZS GŠ).

\section{Transformation to the Democratic Intelligence Service Model}

The transformation process from the totalitarian security apparatus in Czechoslovakia, and later in the Czech Republic, to a modern, democratic, intelligencecommunity model was somewhat complicated. There were several key events, and from some perspectives, as will be shown later, the transformation process is not yet fully completed.

In a short overview, several phases of the transformation process and some main events can be identified ${ }^{6}$ :

\section{Transition Phase, 1989-1992}

- The abolishment of most of the State Security directorates.

- The establishment of the Office for the Protection of the Constitution and Democracy (Úřad pro ochranu ústavy a demokracie - ÚoúD) as a part of the Federal Ministry of Interior. It was later renamed as the Federal Information Service of the Federal Ministry of Interior (Federální informační služba Federálního ministerstva vnitra - FIS FMV).

- The establishment of the Intelligence Service of the Federal Ministry of Interior (Zpravodajská služba Federálního ministerstva vnitra - ZS FMV), later changed to the Office for Foreign Relations and Information of FMV (Úřad pro zahraniční styky a informace FMV - ÚZSI FMV).

- Military Counterintelligence (3rd Directorate of the National Security Corps) was transferred into the structure of the Ministry of National Defense (Ministerstvo národní obrany - MNO) as the Main Directorate of the Military Counterintelligence of Ministry of Defense (Hlavní správa vojenské kontrarozvědky Ministerstva obrany), later renamed as the Directorate of the Military Defensive Intelligence of Czechoslovak Armed Forces (Správa vojenského obranného zpravodajství Československé armády), also already called Military Defensive Intelligence (Vojenské obranné zpravodajství - VOZ).

- The establishment of the Federal Security Information Service (Federální bezpečnostní informační služba - FBIS) as an independent institution by Act No. 244/1991 Coll.

- Act No. 67/1992 Coll., on Military Defensive Intelligence.

6 Description of the transformation phases is based mainly on the publications: Karel Zetocha, Zpravodajské služby v nové demokracii (Česká republika, Brno: Společnost pro odbornou literaturu Barrister\&Principal, 2009) and Ladislav Pokorný, "Transformace československých (a českých) zpravodajských služeb" [Transformation of the Czechoslovak (and Czech) Intelligence Services], Security Theory and Practice 2 (Prague: Police Academy of the Czech Republic, 2018): 57-76. 
Transformation Phase, 1992-1994

- The division of Czechoslovakia into the Czech Republic and the Slovak Republic (January 1, 1993)

- Act No. 527/1992 Coll., Czech National Council Act on Security Information Service of the Czech Republic

- Act No. 153/1992 Coll., on intelligence services of the Czech Republic

- Act No. 154/1992 Coll., on Security Information Service.

Transformation Phase, 1995 - ...

- Act No. 289/2005 Coll., on Military Intelligence brought the effective merging of the Military Defensive Intelligence and Military Intelligence Service into one united Military Intelligence organization.

- Act No. 325/2017 Coll., which changed Act No. 153/1994 Coll., on intelligence services of the Czech Republic - and resulted in significant changes in the control of the intelligence services.

In the following sections, the transformation process of the Czechoslovak (Czech) intelligence community will be described in more detail.

\section{Transition Phase, 1989 - 1992}

Directly after the change of power in November 1989, there was a three months' gap when State Security was practically without any effective control. Although not conducting any operational activities, this time was (mis)used by many officers to destroy a substantial number of operative files, which created obstacles to later efforts to reconstruct the record of its activities during the communist regime.

By order No. 16 of the Federal Minister of Interior from January 31, 1990, all operative directorates of the State Security were abolished (except the 3rd Directorate - Military Counterintelligence), and the next day the following new offices were established:

- The Office for Protection of the Constitution and Democracy at the Federal Ministry of Interior (Úřad pro ochranu ústavy a demokracie FederáIního ministerstva vnitra - ÚOÚD FMV)

- The Intelligence Service of the Federal Ministry of Interior (Zpravodajská služba Federálního ministerstva vnitra - ZS FMV).

This order can be considered to be the basic step (like a big sweep) on the way to the transition from the totalitarian, repressive security apparatus to the democratic model of today's intelligence services. Many other steps (such as new orders and acts) followed, leading to the current organization of the Czech intelligence community (see next sections).

By order of the Federal Ministry of Interior No. 71, on June 1, 1990, the military counter-intelligence, 3rd Directorate of the National Security Corps, was 
transferred to the Ministry of National Defense as the Main Directorate of the Military Counterintelligence of the Ministry of Defense (Hlavní správa vojenské kontrarozvědky Ministerstva obrany), later renamed as the Directorate of the Military Defensive Intelligence of the Czechoslovak Armed Forces (Správa vojenského obranného zpravodajství Československé armády).

The Office for the Protection of the Constitution and Democracy at the Federal Ministry of Interior (ÚOÚD FMV), which had existed for the previous six months, was converted to the Federal Information Service of the Federal Ministry of Interior on January 1, 1991. On May 29, 1991, the Federal Assembly of Czechoslovakia passed Act No. 244/1991 Coll., on the Federal Security Information Service and on the usage of intelligence means. According to this act, a new Federal Security Information Service (Federální bezpečnostní informační služba - FBIS) was established on July 1, 1991. This act was new in several ways:

- for the first time, the mandate of the intelligence service was regulated by law;

- the intelligence service was established without any executive power;

- for the first time, the specific means of information gathering were stated in law;

- the term "person acting in favor" as the designation of a human source of information was mentioned for the first time;

- for the first time, an intelligence service was to be controlled by the Parliament;

- the FBIS Director was appointed by the President but responsible to Parliament.

This act specified the competences of FBIS as an intelligence institution, the ways of fulfilling the tasks in matters of internal order, the security of the state, and its constitutional system. The FBIS is required to provide information pertaining to:

- protection of constitutional order;

- activities of foreign intelligence services;

- foreign-sponsored terrorism;

- activities against state's security;

- $\quad$ protection of the state's economic interests.

The FBIS act was the first of its type in the territory of Czechoslovakia. It meant the end of the core phase of the transformation of the totalitarian security apparatus and, at the same time, the beginning of the new (democratic) era in the area of the Czech intelligence services.

The Directorate of the Military Defensive Intelligence of the Czechoslovak Armed Forces (Správa vojenského obranného zpravodajství Československé armády), as the military counter-intelligence service was renamed in 1992 by Act No. 67/1992 Coll., became the second intelligence service, the activities of which 
were regulated by law and controlled by Parliament. Act No. 67/1992 was similar to the Federal Security Information Service act in all its main features.

In this period, the military external intelligence service-the Intelligence Directorate of the General Staff (Zpravodajská správa generálního štábu Československé armády - ZS/GŠ ČSA) - remained practically the same as an integral part of the General Staff of the Czech Armed Forces and subordinated to the Chief of the General Staff (CoGS).

The name of the Intelligence Service of the Federal Ministry of the Interior (Zpravodajská služba Federálního ministerstva vnitra - ZS FMV) was in the meantime changed to the Office for Foreign Relations and Information of FMV (Úryad pro zahraniční styky a informace FMV - ÚZSI FMV).

The significant feature from the phases of transition mentioned above was the focus on the internal intelligence (counter-intelligence) services. Based on the experience during the communist regime, they were considered to be its main repressive tool. After a very short period of idealistic examination, it was decided that there would be no place for such an organization in a new democratic society, but the existence of a counter-intelligence service was recognized as being a necessary element of the security apparatus. As a consequence, this led to the relatively quick adoption of the respective acts, which would reduce, as much as possible, any threat to society and human rights from the potential possessed by those services.

Both external intelligence services remained organic parts of the respective ministries (Ministry of Defense and Federal Ministry of the Interior) and, as the first step on the way to their transformation, in 1990 they stopped all operational activities against western nations, which were previously their main target but were now seen as prospective allies.

The first period of transformation was very chaotic. Changes were made to the standard institutional processes, and new laws and institutional grounds for the new regime were created. As the former dissident and later intelligence officer Schneider states, "Transformation of intelligence system after 1989 was motivated by ideology and politics, not by security drivers" and "without any expert criteria, but it was power tool, which paradoxically forced new operatives to accept old habits." Interestingly, this view of the transition process was also supported by the former Director of VOZ (Military Defensive Intelligence), Jan Duchek. ${ }^{7}$

To illustrate the situation, especially from the perspective of the top management in these times, here is the list of directors of the ÚZSI FMV (external intelligence service) in the period of 1990-1992:

7 Jan Duchek, "Zpravodajské služby při tvorbě a realizaci bezpečnostní politiky [Security Services in the Development and Implementation of Security Policy]," Vojenské rozhledy [Czech Military Review], no. 1 (2005), www.vojenskerozhledy.cz/images/ archiv_voj_rozhl/clanky/2005/Rozhledy2005-1/rozhledy2005-1_Zpravodajske_ sluzby_pri_tvorbe_a_realizace.pdf. 
- January - April 1990, Přemysl HOLAN

- May - June 1990, Bohumil KUBík

- July - August 1990, PřemysI HOLAN

- September 1990 - December 1992, Radovan PROCHÁZKA.

Similar was the situation in its civilian domestic intelligence counterpart (ÚOÚD FMV, FI FMV, FBIS):

- February - April 1990, Zdeněk FORMÁNEK

- April - June 1990, Jan RUML

- June - November 1990, Jiří MÜLLER

- November 1990 - December 1991, Jiří NOVOTNÝ

- January - August 1992, Štefan BAČINSKÝ

- September - December 1992, Pavol SLOVÁK.

From the personnel perspective, the following main trends are significant for this first phase:

- Some of the officers who were fired from the Service after the Soviet occupation in 1968 (due to their reform activities in the late 1960s and/ or disagreement with the Soviet occupation) returned to the services, usually to management positions. Their main advantages were their professional experience from the previous service (e.g., Přemysl, Holan, Jan Duchek).

- Another group of newcomers to the services (and sometimes going directly into management positions) were former dissidents, people who were in opposition to the communist regime. They should guarantee democratic direction and activity within the services, but the problem, in some cases, was that their only experience in this field was their persecution by the communist State Security (e.g., Oldřich Černý, Petr Zeman, Radovan Procházka).

- On the other hand, the vetting process of former State Security officers with the aim of checking their ability to serve in the new democratic intelligence services had begun. The civil vetting commissions were especially strict in checking officers who had previously worked in the counter-intelligence directorates.

- Some of the former members of the communist security institutions also left the service voluntarily because they did not agree with the changes in the political regime.

The organizational structure, subordination, and oversight of the Czechoslovak intelligence community at the end of this transitional phase is illustrated in Figure 1. 


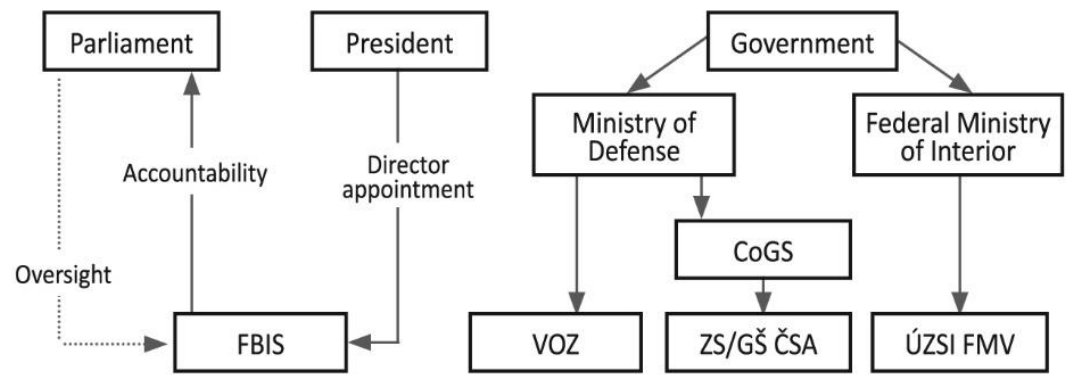

Figure 1: Organizational Structure of the Czechoslovak Intelligence Services in 1992.

\section{Transformation Phase, 1992-1994}

In this phase, the main issue was the division of Czechoslovakia into two independent states - the Czech Republic and the Slovak Republic. The negotiations on the division were conducted during the second half of 1992, and the new states were officially established on January 1, 1993. Already in 1992, practical measures were taken towards the delimitation of federal institutions, including the security apparatus and the armed forces. Except for the physical movement of many materials (e.g., weapons), a significant number of personnel was moved in accordance to the future nationality that they claimed and to the new institutions that needed to be established.

In the area of intelligence services, the main change was the establishment of the Security Information Service of the Czech Republic by Act No. 527/ 1992 Coll.-Czech National Council Act on the Security Information Service of the Czech Republic-as the provisional law framework for the establishment of the new Czech Republic. According to this act, the Security Information Service of the Czech Republic (Bezpečnostní informační služba České republiky - BIS ČR) was, for the first time, defined as being a state institution, then as an armed security service, and as a government agency with an independent allocation from the state budget. ${ }^{8}$ The service functions were copied from the previous FBIS functions, with the later addition of another function concerning organized crime.

In this phase, the main event was the adoption of a new so-called "umbrella" act on intelligence services - Act. No. 153/1994 Coll., on the intelligence services of the Czech Republic. This act covers all the intelligence services - external, internal, military, and civilian. The act defines the status of the intelligence services, their mandates, tasks, competences, Director's appointment, tasking, re-

8 Previous, very unique subordination to the Parliament was assessed as ineffective and the intelligence service of the new Czech Republic moved again to the executive branch. 
quirements, and submission of information. This act has remained valid until today, with some amendments.

The tasks of the services were defined in $\S 5$ of Act. 153/1994 as follows.

The Security Information Service (BIS) provides information on:

- $\quad$ schemes and activities directed against the democratic foundations, the sovereignty, and the territorial integrity of the Czech Republic

- the intelligence services of foreign powers

- activities endangering state and official secrets

- activities, the consequences of which, may jeopardize the security or major economic interests of the Czech Republic

- information regarding organized crime and terrorism.

Military Intelligence (VZ) provides information:

- of foreign provenance, which is important for the security and defense of the Czech Republic ${ }^{9}$

- $\quad$ on the intelligence services of foreign powers in the area of defense

- $\quad$ on schemes and activities directed against the interests of safeguarding the defense of the Czech Republic

- on activities endangering classified information within the area of defense of the Czech Republic.

The Office for Foreign Relations and Information (ÚZSI) provides information on foreign provenance that is important for the security and protection of the foreign political and economic interests of the Czech Republic.

All intelligence services will also fulfill other tasks defined by specific legislation or international treaties by which the Czech Republic is bound.

The special Act No. 154/1994 Coll. on the Security Information Service that was adopted at the same time defined, first of all, specific means of collecting information, ${ }^{10}$ the status and terms of employment of service members, and parliamentary oversight. This service was from that time referred to only as BIS, without the ČR supplement.

Until 2005, Military intelligence was defined in Act No. 153/1994 as follows: "Military Intelligence (VZ) is formed by the Military Intelligence Service (VZSI) and the Military Defensive Intelligence (VOZ)." This construct created some rather strange arrangements, such as:

9 This task was designated to the external military intelligence service (VZSI), the rest were tasks of the internal part of military intelligence (VOZ) and if one compares the tasks of ÚZSI, there is obvious collision or overlap ("security of the Czech Republic"), causing certain problems in the coordination of their activities (see the following text).

10 The specific means of collecting (or acquiring) information are as follows: 1 . intelligence means (intelligence technology, covert means and documents, surveillance), 2. using of persons acting in favor of the service (i.e., informants). See also Petr Zeman, Intelligence Services of the Czech Republic: Current Status and its Development. 
- Only the defensive part of Military Intelligence was regulated by law (by special Act. No. 67/1992 Coll., on Military Defensive Intelligence).

- The position of the Director of Military Intelligence (VZ) was, more or less, formal (he had only a very small office), and he was accountable to the Minister of Defense. The Directors of VOZ and VZSI were subordinated to him, but only in a very limited range, which excluded "the sphere of special activities."

- $\quad$ The VZSI Director (whose personal title was changed from time to time - chief, inspector, or director) was, in professional matters, simultaneously subordinated to the VZ director and the Chief of the General Staff of the Armed Forces of the Czech Republic (AČR).

- The VOZ Director was, at the same time, directly subordinate to the Minister of Defense.

In that time, a popular bon mot said: "There are three services in the act, four in reality, with five directors." This situation continued until 2001, when one person (Jiří Giesl) became, at the same time, VZ Director and VOZ Director. The complete merger of both services occurred in 2005.

Although the situation at the end of 1994 (see the overall picture of the organization and management is in Figure 2) fit the requirements of most of the aspects of the intelligence and security services of a democratic state, there were still some remaining unsolved issues. These included the complicated organization and management of the military intelligence services, especially:

- The external intelligence services (ÚZSI and VZSI) were not subjected to parliamentary oversight.

- The legal framework of the external services was generally relatively poor. They were regulated only by several paragraphs of the umbrella act No. 153/1994 Coll. on the Czech Republic's intelligence services.

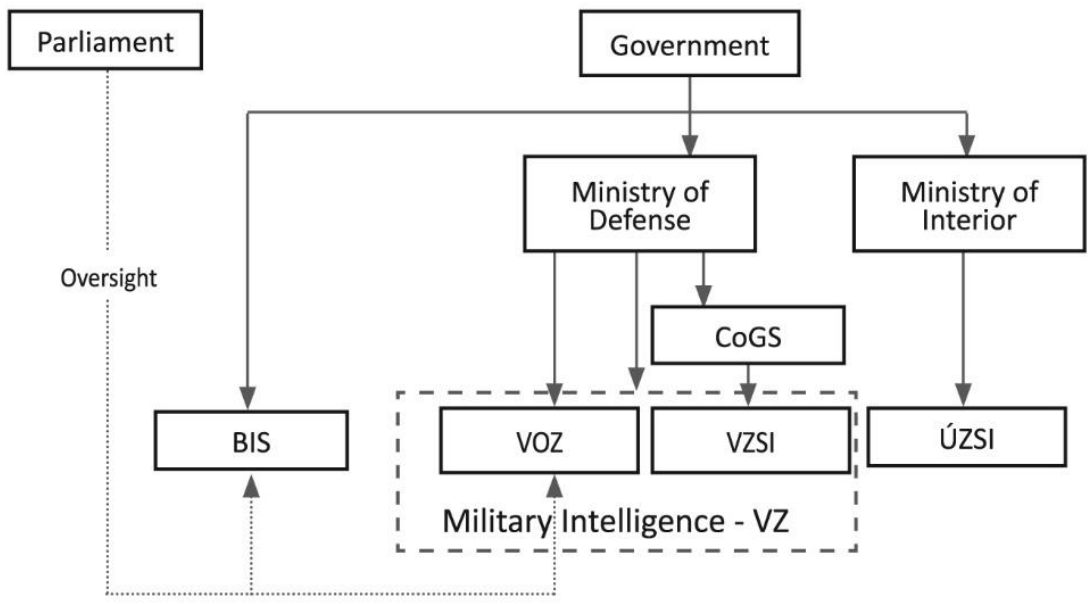

Figure 2: Organizational Structure of the Czech Intelligence Services in 1994. 


\section{Transformation Phase, 1995 until Now}

The last phase of transformation, which, as will be shown later, is not yet completely finished, is characterized mainly by changes in the area of military intelligence services and in the system of oversight of the intelligence services (the situation as of 2019 is presented below in Figure 3).

As was mentioned above, the organizational structure and management of Military Intelligence (MI) were very complicated. So, in 2005 a new Act No. 289/ 2005 Coll. on Military Intelligence was adopted. It effectively merged the internal (VOZ) and external (VZSI) intelligence services into one united organization. The Director was subordinated to the Minister of Defense. A significant feature of this merger was a big change of personnel. As Zeman wrote: "From about 2004, military intelligence had been undergoing a crucial change of personnel; VZ members, serving before November 1989, had to leave the service, with a delay of 10-12 years in comparison to civilian services."

Until 2014, the 601st Special Forces Group ${ }^{11}$ was part of the Military Intelligence organization. After many disagreements on these issues, a decision was made, and this unit was transferred to the Special Operations Directorate of the Ministry of Defense (Ředitelství speciálních sil Ministerstva obrany).

The last main change in the intelligence system of the Czech Republic occurred in 2017 when an amendment to Act No. 153/1994 regarding oversight of intelligence services was adopted - Act No. 325/2017 Coll. This changed parts of Act No. 153/1994 Coll. on the Czech Republic's intelligence services. The most significant changes are as follows:

- The establishment of a Parliamentary committee for the oversight of the external intelligence service (ÚZSI)

- The establishment of a new, Independent body for the oversight of the intelligence services (see next section).

The Intelligence Activity Committee (Výbor pro zpravodajskou činnost - VZČ) conducts the coordination of the intelligence services at the government level. This Committee is a permanent body established as one of the working committees of the National Security Council (Bezpečnostní rada státu - BRS). The Prime Minister heads the Intelligence Activity Committee. Its members are the Minister of Foreign Affairs, the Minister of Defense, the Minister of the Interior, the Directors of all three intelligence services (BIS, VZ, ÚZSI) and the Director of the Office of the Government.

\section{Oversight of the Intelligence Services in the Czech Republic}

The oversight and/or control of intelligence and security services are generally sensitive and, in democratic states, an important legal issue. Many documents

11 The mission of the unit was generally defined by the tasks of special forces according to NATO documents and by highest national command and included special reconnaissance, assault actions and other special tasks (e.g., rescue missions, assistance to the Ministry of Interior, protection of embassies, etc.). 


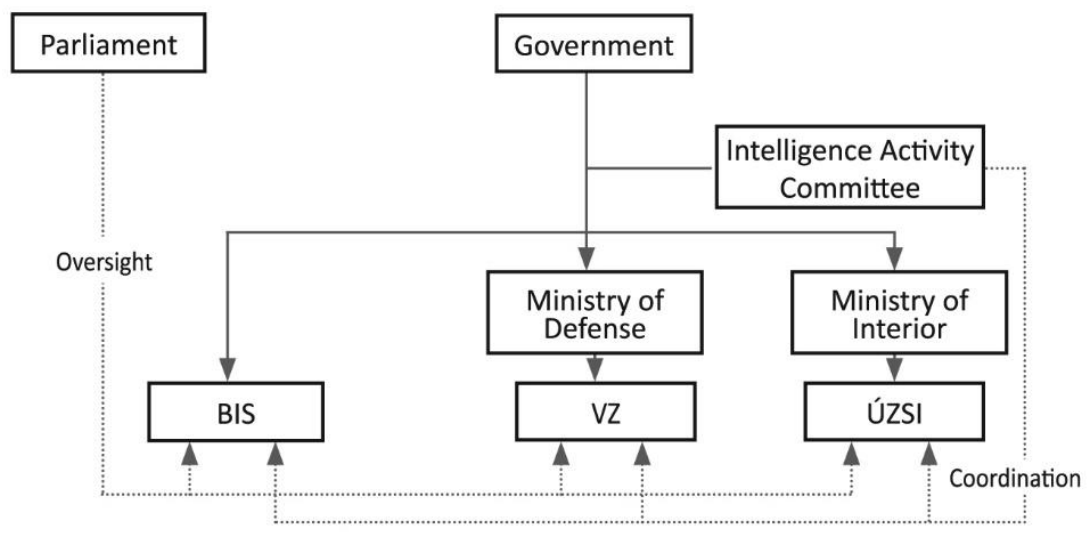

Figure 3: Organizational Structure of the Czech Intelligence Services as of 2019.

and studies have been published in this field, especially during the last 20 years. Czech lawmakers have been trying to establish proper control of the intelligence services with a mechanism for oversight that is in line with the best practices of other democratic countries. Their ideas have been based, specifically, on the recommendations of respected European institutions. Before dealing specifically with the Czech Republic situation, it is useful to mention the main documents that inspired the experts and lawmakers in this area. One of the main authorities in democratic Europe in this area is the Council of Europe, which has issued several relevant, complex documents on this topic. Many more relevant and useful publications and links in the area of control and oversight of intelligence and security services are also available on the website of the Geneva Centre for the Security Sector Governance (DCAF).

From the broadest perspective, the control of the intelligence services can be divided into internal and external aspects. The internal control mechanisms of the Czech intelligence services will be described in the next section. The external, civilian oversight of the intelligence services in the Czech Republic can be further divided into the following areas:

1. Executive control

2. Legislative (or Parliamentary) oversight

3. Judicial review

4. Independent oversight

5. Public and media control.

Executive control. First of all, the Czech Republic's intelligence services are part of the executive, and the government of the Czech Republic is primarily responsible for their management and activities. Governmental control is mainly fulfilled by giving directions and tasks to the intelligence services; through the 
control of the budget and, at the personnel level, by the appointment and dismissal of intelligence services' directors. In practice, every year, the government issues a list of priorities for intelligence activity (a classified collection plan). Consequently, the intelligence services provide the government with several different reports: annual (classified ${ }^{12}$ ) reports, reports on-demand, and reports submitted by intelligence services on their own initiative. Organizationally, executive control is conducted through the respective Ministries (of Defense and Interior) and through the Committee on Intelligence.

Legislative (or Parliamentary) oversight is conducted by special oversight bodies of the Parliament of the Czech Republic. These oversight bodies, known as Permanent Commissions for the control of all intelligence services, are established by the Chamber of Deputies of the Parliament of the Czech Republic (Poslanecká sněmovna Parlamentu České republiky). The mandate for those commissions is relatively limited and covers the oversight of internal regulations, the budget, and tasks allocated by the government and the President. The Commissions cannot control the ongoing activities (operations) of the intelligence services.

Judicial review is the oversight conducted by the judicial branch. The main task of the judicial review system is to check the law relating to the use of specific means of information gathering. This is because the use of intelligence technology could interfere with the rights and freedoms of ordinary citizens. The use of intelligence technology has to be approved by a judge from the respective High Court in the location of the service's headquarters. Practically, this means the High Court in Prague because both BIS and VZ headquarters are located in the capital city. A judicial review is conducted not only a priori, in the phase before the actual use of intelligence technology, which results in official approval of its use by a proper judge but, it can also be done ex post facto in the course of the use of intelligence technology. The judge has to assess whether the reasons for the use of intelligence technology persist. If the judge determines that the reasons for the use of intelligence technology have ceased to exist, he/ she can withdraw the warrant for its use.

The external intelligence service (ÚZSI) is not, from this perspective, the subject of any judicial reviews because it is not authorized to use such means inside the territory of the Czech Republic.

The Independent Oversight Body. Since 2018, a new oversight body has been established - The Independent Oversight Body. It conducts de facto, secondlevel oversight because it has superior competences than the first level of oversight, which is conducted by special Parliament control bodies. The appropriate special Parliament Oversight Commission (for BIS, VZ, or ÚZSI) initiates its control activity, and it is to that Commission that the final report is submitted. According

12 These annual classified reports to the government are provided by all three intelligence services (BIS, VZ, and ÚZSI) and contain more detailed and sensitive information than the unclassified annual public report provided only by BIS and VZ. 
to law, the Independent Oversight Body consists of five members. They are independent experts ${ }^{13}$ proposed by the government and then selected and appointed by the Chamber of Deputies of the Parliament of the Czech Republic for a period of five years. Currently, this system is not working effectively because of the short time since the adoption of the specific changes in the law and the fact that the members of the Commission have not been appointed yet.

Public and media control. There are several formats of this type of control in the current Czech Republic. First of all, the intelligence services are subject to Act No. 106/1999 Coll., on the free access to information, as are all other government institutions. It means that they have to provide information on many of the questions being asked of the service. However, according to the special act, the Service is not required to provide answers to questions about either classified information or specific intelligence activity (operations).

The internal intelligence service (BIS) and the military intelligence service (VZ) regularly publish Annual Reports on their activities. Every year, after these reports have been published, they become the subject of intense media discussion and, even later, the information provided by the services are screened and investigated by journalists. At the same time, journalists are always looking for any breaches in the activities of the intelligence services and any information leaks.

The internal intelligence service (BIS) and the military intelligence service (VZ) have official spokespersons. Whenever an intelligence-related issue attracts the interest of the public, journalists regularly seek information from these spokespersons, especially the one from the BIS.

\section{Lessons Learned, Recommendations and Remaining Challenges}

Based on an assessment of the actual transformation processes of the Czech intelligence services from a totalitarian security apparatus, some specific factors can be identified in comparison with the same processes of change in other former socialist countries such as Poland, Hungary, and East Germany. First, it was a reinstatement of a significant number of former SNB members who, due to their reform activities in the late 1960s and/or their disagreement with the Soviet occupation, had been removed from the service after the Soviet occupation in 1968. Another significant feature was the extensive involvement of the civil vetting commissions in the process of assessment of the eligibility of former members of the State Security for service in both the new intelligence services and the police.

13 A member of the Independent Oversight Body cannot be the President of the Czech Republic, government minister or deputy minister, Deputy or Senator, Deputy of European Parliament, judge, regional parliament deputy, member or employee of the security corps of the Czech Republic, a professional soldier or employee of the Armed Forces of the Czech Republic. Note: Security corps of the Czech Republic are as follows: Police of the Czech Republic, Prison Service of the Czech Republic, Fire Rescue Service of the Czech Republic, General Inspection of the Security Corps, Security Information Service, Custom Service, and the Office of Foreign Relations and Information. 
Among the former Soviet bloc countries, at least in civilian intelligence services, the Czech Republic was the closest to the so-called "null variant," which means that it built the new services from zero on the "green grass." ${ }^{14}$ The exchange of personnel in the other countries was on a much less level playing field.

The early stages of the transformation were not conducted on the basis of a rational and elaborate plan. Sometimes it took leaps and bounds and unpremeditated changes; sometimes, it was based on very individual and subjective ideas. ${ }^{15}$ In reality, this means that the legal situation in the Czech Republic was a case of law discontinuity in this specific area. Because there was no existing legislation, the core changes can be described as a journey from non-regulation to regulation based on the best practices and experiences of the developed, democratic countries without relics of existing previous legislation. It is necessary to say, though, that despite the big move forward, the legislation in the first period of transformation (from transition to 1992) did not fully comply with the democratic standards that were later set up in, for example, the DCAF documents.

Only Acts No. 153/1994, on the intelligence services of the Czech Republic and No. 154/1994, on the Security Information Service produced the complex legislation, which concluded the stage of establishing a standard legal regulation of the Czech Republic intelligence system. These acts can be considered to be the closure of the first phase of the Czech Republic intelligence transformation process (by 1994).

A more narrow concept of the mandate of the intelligence services was clearly embedded in the form of the Czech legal regulation of the intelligence services. The application resulted in a requirement for separation between the intelligence services and the police authorities and the absence of any executive powers of a police-type or law enforcement powers in the intelligence services. The Czech Republic's intelligence services have been defined as state authorities with no executive powers and which are not among the law enforcement authorities. This accurately describes the range of powers granted to them and the extent of the applicability of the information obtained by them.

14 The former Director of ÚZSI Oldřich Černý in his article "Pár poznámek k problematice zpravodajských služeb v ČR" describes this time of changes by following words: "Czechoslovakia and later the Czech Republic were building their intelligence community on green grass (I speak on the civilian internal and external services only...) and despite the generous foreign assistance it was a process of tests and mistakes, "hits and misses" and those misses were much more than "hits." Oldřich Černý, "Pár poznámek k problematice zpravodajských služeb v ČR" (Europeum Institut pro evropskou politiku, 2008), http://old.europeum.org/doc/pdf/Oldrich_Cerny_zari_final.pdf.

15 For example, Igor Cibula talks about the proposal of then Federal Minister of Interior Ján Langoš to stop completely operative activity of the Czechoslovakian external intelligence services and thus in practice to dissolve external intelligence service. Igor Cibula, "Zmeny v spravodajských službách po skončení studenej vojny, resp. skončení bipolárního usporiadania světa," in Zmeny v spravodajských službách, Collection of contributions from a conferece in Bratislava, December 4, 2007 (Bratislava: BVŠPABSD, 2008), www.absd.sk/upload/file/Zmeny_v_spravodajskych_sluzbach.pdf. 
The 1994 legislation enshrined a state of high stability and, through several successive amendments, this still exists today at the basic level. It has created a prerequisite for the standard operation of intelligence services on the principles of the rule of law. With the exception of the Military Intelligence, where the time frame is somewhat shorter, for almost a quarter of a century, this has produced a high degree of stability, which is a desirable state for regulating the legal and intelligence systems. However, in many aspects, recent developments have shown the need for further modernization of the law to allow the most efficient use of the intelligence services, especially in the face of new forms of terrorism and the associated phenomena.

From the topics discussed, it is possible to identify the most important occurrences in recent years:

- the extension of the external control of the intelligence services;

- the possible use of intelligence from intelligence sources as evidence in trials; and

- the modification of some aspects of the principle of separation that is still, unreservedly, applied to the mandate and character of the Czech intelligence services.

The requirement to extend the external control of intelligence services, including the creation of an independent control body, was, in principle, fulfilled by the adoption of Act No. 325/2017 Coll., amending Act No. 153/1994 Coll., on the intelligence services of the Czech Republic.

A legal solution has still to be found to allow the possible evidential use of intelligence-related information. This intention is already contained and formulated in some governmental measures, especially in the so-called National Security Audit.

Certain modifications of some aspects of the imperative principle of separation should, according to the proposed amendment to the Act on Military Intelligence, entrust the provision of the cyber defense of the Czech Republic to Military Intelligence.

\section{Sources and Readings}

\section{Books and Articles}

Audit národní bezpečnosti [National Security Audit], approved by Government Resolution No. 1125 from December 14, 2016, www.vlada.cz/assets/mediacentrum/aktualne/Audit-narodni-bezpecnosti-20161201.pdf.

Born, Hans, and lan Leigh. Making Intelligence Accountable: Legal Standards and Best Practices for Oversight of Intelligence Agencies. Oslo: Publishing House of the Parliament of Norway, 2005. https://www.dcaf.ch/sites/default/files/ publications/documents/making-intelligence.pdf. 
Democratic and Effective Oversight of National Security Services. Issue paper published by the Council of Europe, Commissioner for Human Rights. Prepared by Aidan Wills. Strasbourg, 2015. https://rm.coe.int/16806daadb.

Černý, Oldřich. Czechoslovak (Czech) Intelligence after the Cold War. Paper presented at the Workshop on "Democratic and Parliamentary Oversight of Intelligence Services," held in Geneva 3-5 October 2002. Geneva Centre for the Democratic Control of Armed Forces.

Černý, Oldřich. Zpravodajské služby a uživatelé zpravodajských informací. In Ludský faktor v zpravodajských službách. Collection of contributions from the conference in Bratislava, December 9, 2009. BVŠP-ABSD, Bratislava, 2009. http://www.absd.sk/sympozium_ludsky_faktor_v_spravodajskych_sluzbach.

Černý, Oldřich. Pár poznámek k problematice zpravodajských služeb v ČR. Europeum, Institut pro evropskou politiku, 2008. http://old.europeum.org/doc/ pdf/Oldrich_Cerny_zari_final.pdf.

Cibula, Igor. Zmeny v spravodajských službách po skončení studenej vojny, resp. skončení bipolárního usporiadania světa. In Zmeny v spravodajských službách. Collection of contributions from the conferece in Bratislava December 4, 2007. BVŠP-ABSD, Bratislava, 2008. http://www.absd.sk/upload/file/Zmeny_v_spravo dajskych_sluzbach.pdf.

Duchek, Jan. Zpravodajské služby při tvorbě a realizaci bezpečnostní politiky. Vojenské rozhledy 1 (2005): 41-58.

History of the UZSI. From 1990 to 1995. Part I. From the dissolution of SNB Directorate I to the emergence of the Office of the FMI for Foreign Relations and Information. Internal, unpublished document. Praha: ÚZSI.

European Commission for Democracy through Law. Internal Security Services in Europe. Secretariat Memorandum based on the opinion of Lundum, John, Said Pullicino, Joseph and Antti Suviranta. No. 039/1997. http://www.venice.coe.int/ webforms/documents/?pdf=CDL(1998)011-e.

Michálek, Luděk, Ladislav Pokorný, Jozef Stieranka, and Michal Marko. Zpravodajství a zpravodajské služby. Plzeň: Aleš Čeněk, 2013.

Pokorný, Ladislav. Zpravodajské služby. Praha: Auditorium, 2012.

Pokorný, Ladislav. Transformace československých (a českých) zpravodajských služeb. [Transformation of the Czechoslovak (and Czech) Intelligence Services]. Security Theory and Practise 2 (2018): 57-76.

Pokorný, Ladislav, Jiří Chrobák, and Martin Fliegel. Zákon o zpravodajských službách ČR, Zákon o Bezpečnostní informační službě, Zákon o Vojenském zpravodajství. Komentár. Praha: Wolters Kluwer ČR, 2018. 
Pokorný, Ladislav. K první zákonné úpravě zpravodajských služeb u nás. Security Theory and Practise 4 (2011): 67-78.

Pokorný, Ladislav. Aktuální otázky postavení a kompetencí zpravodajských služeb České republiky. In Bezpečnostní hrozby současnosti, ed. B. Vegrichtová et al. Praha: Police Academy of the Czech Republic, 2016, 133-140.

Pokorný, Ladislav. "Zur Entwicklung der rechtligen Regelungen der Nachrichtendienste der Tschechischen Republik." In Festschrift zum 25-jahrigen Bestehen der Schule fur Verfassungsschutz und fur Andreas Hubsch, 433-449. Bruhl, Rheinland, 2007.

Růžek, Jiří. V labyrintu zpravodajských služeb. Praha: Šulc-Švarc, 2014.

Schneider, Jan. Reforma zpravodajských služeb v České republice. Europeum, Institut pro evropskou politiku, 2008. http://old.europeum.org/doc/pdf/Jan_ Schneider_zari_final.pdf

Williams, Kieran, and Dennis Deletant. Security Intelligence Services in New Democracies. The Czech Republic, Slovakia and Romania. New York: Palgrave, 2001.

Zeman, Petr. Intelligence Services of the Czech Republic: Current Status and its Development. Geneva: DCAF, 2007. https://www.dcaf.ch/sites/default/files/ publications/documents/zeman_intelligence-services-czech.pdf.

Zeman, Petr, ed. Česká bezpečnostní terminologie (Czech Security Terminology). Brno: Masarykova univerzita, 2003.

Zeman, Petr. České zpravodajské služby po roce 1989. In Kapitoly o bezpečnosti, edited by Balabán, M., Stejskal, L. a kol. Praha: Karolinum, 2010.

Zeman, Petr. Spolupráce zpravodajských služeb v EU a její limity. In Evropská unie a jeji bezpečnost. Vybrané problémy evropské bezpečnosti, edited by J. Závěšický. Brno: Mezinárodní politologický ústav MU, 2006.

Zeman, Petr. Transformace zpravodajských služeb v Československu a České republice. In Zkušenosti české transformace, edited by L. Veselý. Praha, 2005. https://www.clovekvtisni.cz/media/publications/360/file/1422350512-ceskazkusenost-transformace.pdf.

Zeman, Petr. Transformace zpravodajských struktur v postkomunistických zemích - příklad Československa a Česka. In Zmeny v spravodajských službách. Sborník příspěvků ze sympózia Bratislava, Janury 4, 2007. BVŠP-ABSD, Bratislava, 2008. http://www.absd.sk/upload/file/Zmeny_v_spravodajskych_sluzbach.pdf.

Rozkaz ministra vnitra České a Slovenské federativní republiky, č. 71 ze dne 31. 5. 1990. (Order No. 71 of the Federal Ministry of Interior from 31 May, 1990). http://old.ustrcr.cz/data/pdf/rozkazy/orstb71-89/rmv_71_1990.pdf.

Zetocha, Karel. Zpravodajské služby v nové demokracii. Česká republika. Společnost pro odbornou literature. Brno: Barrister \& Principa, 2009. 


\section{Related Websites}

Bezpečnostní informační služba [Security Information Service], www.bis.cz

Úřad pro zahraniční styky a informace [Office for Foreign Relations and Information], http://uzsi.cz/cs/

Vojenské zpravodajství [Military Intelligence], https://www.vzcr.cz

Výbor pro zpravodajskou činnost [Intelligence Activity Committee], https://www.vlada.cz/cz/ppov/brs/pracovni-vybory/zpravodajskacinnost/vybor-pro-zpravodajskou-cinnost-3858/

Bezpečnostní rada státu [National Security Council], https://www.vlada.cz/en/ pracovni-a-poradni-organy-vlady/brs/office-of-the-government-of-the-czechrepublic-23851/

Ředitelství speciálních sil [Special Forces Directorate], http://www.acr.army.cz/ struktura/generalni/specialni-sily/reditelstvi-specialnich-sil-104392/

Ústav pro studium totalitních režimů [Institute for the Study of Totalitarian Regimes], https://www.ustrcr.cz

Asociácia bývalých spravodajských dôstojníkov [Association of Former Intelligence Officers], http://www.absd.sk

Geneva Centre for the Democratic Control of Armed Forces (DCAF), www.dcaf.ch

Poslanecká sněmovna Parlamentu České republiky [Chamber of Deputies of the Parliament of the Czech Republic], http://www.psp.cz/sqw/hp.sqw?k=195

Cibulkovy seznamy, http://cs.wikipedia.org/wiki/Cibulkovy_seznamy

Archív bezpečnostních složek, https://www.abscr.cz

\section{Legal Acts}

Zákon č. 40/1974 Sb., o Sboru národní bezpečnosti [Act No. 40/174 Coll. on the National Security Corps.], https://www.zakonyprolidi.cz/cs/1974-40\#f3527802

Zákon č. 244/1991 Sb., o Federální bezpečnostní informační službě a o používání zpravodajských prostředků [Act No. 244/1991 Coll., on the Federal Security Information Service and on the usage of intelligence means], www.zakony prolidi.cz/cs/1991-244

Zákon č. 67/1992 Sb., o Vojenském obranném zpravodajství [Act No. 67/1992 Coll., on Military Defensive Intelligence], www.zakonyprolidi.cz/cs/1992-67

Zákon č. 527/1992 Sb., Zákon České národní rady o Bezpečnostní informační službě České republiky [Act No. 527/1992 Coll., Czech National Council Act on Security Information Service of the Czech Republic], https://www.zakony prolidi.cz/cs/1992-527 
Zákon č. 153/1994 Sb, o zpravodajských službách České republiky [Act No. 153/ 1992 Coll., on intelligence services of the Czech Republic], https://www.zakony prolidi.cz/cs/1994-153

Zákon č. 154/1994 Sb., o Bezpečnostní informační službě [Act No. 154/1992 Coll., on Security Information Service], https://www.zakonyprolidi.cz/cs/1994-154

Zákon č. 289/2005 Sb., o Vojenském zpravodajství [Act No. 289/2005 Coll., on Military Intelligence], https://www.zakonyprolidi.cz/cs/2005-289

Zákon č. 325/2017 Sb., kterým se mèní zákon č. 153/1994 Sb., o zpravodajských službách České republiky, ve znění pozdějších předpisů, a další související zákony [Act No. 325/2017 Coll., which changes act No. 153/1994 Coll., on intelligence services of the Czech Republic], https://www.zakonyprolidi.cz/cs/2017-325

Zákon č. 100/1960 Sb., Ústava Československé socialistické republiky [Act No. 100/1960 Coll., Constitution of the Czechoslovak Socialistic Republic], https://www.psp.cz/docs/texts/constitution_1960.html

Zákon č. 106/1999 Sb. o svobodném prístupu k informacím [Act No. 106/1999 Coll., on free access to information], https://www.zakonyprolidi.cz/cs/1999-106

Zákon č. 412/2005 Sb. o ochraně utajovaných informací a o bezpečnostní způsobilosti [Act No. 412/2005 Coll., on the protection of classified information and security clearance], https://www.zakonyprolidi.cz/cs/2005-412

Zákon č. 451/1991 Sb., kterým se stanoví některé dalši předpoklady pro výkon některých funkcí ve státních orgánech a organizacích České a Slovenské Federativní Republiky, České republiky a Slovenské republiky [Act No. 451/1991 Coll., which defines other conditions for appointment to the selected positions in the state administration and institution of the Czech and Slovak Federative Republic, Czech Republic and Slovak Republic], www.zakonyprolidi.cz/cs/1991451

Zákon č. 279/1992 Sb. Zákon České národní rady o některých dalších předpokladech pro výkon některých funkcí obsazovaných ustanovením nebo jmenováním přislušníků Policie České republiky a príslušníků Sboru nápravné výchovy České republiky [Act No. 279/1992 Coll., Act on some other prerequisites for the performance of certain functions occupied by provisions or the appointment of members of the Police of the Czech Republic and members of the of Prison Service the Czech Republic], https://www.zakonyprolidi.cz/cs/1992-279

Zákon č. 140/1996 Sb., o zpřistupnění svazků vzniklých činností bývalé Státní bezpečnosti [Act No. 140/1996 Coll., on accessing the bundles arising out of the activities of the former State Security], https://www.zakonyprolidi.cz/cs/1996-140

Zákon č. 341/2011 Sb., o Generální inspekci bezpečnostních sborů a o změně souvisejících zákonů [Act No. 341/2011 Coll. on General Inspection of Security Corpses], https://www.zakonyprolidi.cz/cs/2011-341 
Zákon č. 40/2009 Sb., trestní zákoník [Act. No. 40/2009 Coll., Criminal Code], https://www.zakonyprolidi.cz/cs/2009-40?text=trestní+zákon.

Zákon č. 141/1961 Sb., o trestním řizení soudním (trestni rád) [Act No. 141/1961 Coll., Penal Code], https://www.zakonyprolidi.cz/cs/1961-141

Zákon č. 200/1990 Sb., Zákon České národní rady o přestupcích [Act. No. 200/ 1990, Act of Czech National Council on Offenses], https://www.zakonyprolidi.cz/ cs/1990-200

Zákon č. 361/2003 Sb., o služebním poměru přislušniků bezpečnostních sborů [Act No.361/2003 Coll., on the service of the security corps members], https://www.zakonyprolidi.cz/cs/2003-361

\section{Disclaimer}

The views expressed are solely those of the authors and do not represent official views of the PfP Consortium of Defense Academies and Security Studies Institutes, participating organizations, or the Consortium's editors.

\section{Acknowledgment}

Connections: The Quarterly Journal, Vol. 18, 2019 is supported by the United States government.

\section{About the Authors}

Luděk Michálek, PhD, works as a member of the academic staff at the Police Academy of the Czech Republic in Prague, teaching mainly intelligence studies related topics. He has previous, long-term experience from service in the armed force, including military intelligence. E-mail: michalek@polac.cz

Ladislav Pokorný, PhD, works as an Associate Professor at the Police Academy of the Czech Republic in Prague, teaching mainly intelligence-related topics. He has previous long-term experience in the intelligence service.

E-mail: pokorny@polac.cz 